\title{
Friedman Tongue Position with the Obstructive Sleep Apnea Syndrome (OSAS) Correlation on Patient with Ischemic Stroke
}

\author{
Yuniarti, ${ }^{1}$ Alya Tursina, ${ }^{1}$ Shenny Dianathasari Santoso, ${ }^{1}$ \\ Ahda Febianti, ${ }^{2}$ Putri Adinie Esca Nissa ${ }^{2}$ \\ ${ }^{1}$ Department of Anatomy, ${ }^{2}$ Medical Undergraduate Study Program, Faculty of Medicine, \\ Universitas Islam Bandung, Bandung, Indonesia
}

\begin{abstract}
Stroke is the number one cause of disability in the world. Sleep disturbances exacerbate post-stroke disabilities in addition to physical disorders. Sleep disorder breathing (SDB), especially obstructive sleep apnea syndrome (OSAS) is the most commonly found in stroke patients (more than 50\%). Sleep disorders in patients with ischemic stroke may occur because of obstruction in the upper airway. To facilitate the assessment of the upper airway, Friedman set up a standard naso-velo-oropharyngeal examination area. There are four degrees of Friedman tongue position. This check can predict the presence or absence of OSAS. Obstructive sleep apnea syndrome can be assessed using STOP-BANG questionnaire, an instrument designed to rapidly detect obstructive sleep apnea (OSA) disorder, with an indication of score 5-8 is high-risk, $3-4$ is moderate-risk, and $0-2$ is low-risk. The method of this study was observational with cross-sectional design in acute phase ischemic stroke patient based on head CT-scan in RSAU dr. M. Salamun Bandung from August-December 2016. Statistical analysis using non-parametric Kruskal-Wallis test and Spearman's rank correlation test. The total subjects of this study were 38 people. The results showed that there was a significant relationship between Friedman tongue position and OSAS in stroke patients at RSAU dr. M. Salamun with $\mathrm{p}$ value $=0.007$. In conclusion, the tongue is an important anatomical structure in OSA patients, so evaluation of the position of the tongue is important to predict the severity of OSA.
\end{abstract}

Key words: Friedman tongue position, ischemic stroke, obstructive sleep apnea syndrome (OSAS)

\section{Hubungan Derajat Friedman Tongue Position dengan Kejadian Obstructive Sleep Apnea Syndrome (OSAS) pada Penderita Strok Iskemik}

\begin{abstract}
Abstrak
Strok merupakan penyebab disabilitas nomor satu di dunia. Disabilitas pascastrok selain gangguan fisik diperburuk dengan gangguan tidur. Sleep disorder breathing (SDB) terutama obstructive sleep apnea syndrome (OSAS) paling sering ditemukan pada pasien strok (lebih dari 50\%). Gangguan tidur pada penderita strok iskemik dapat terjadi karena obstruksi pada saluran napas atas. Untuk memudahkan penilaian saluran napas atas, Friedman membuat standar pemeriksaan daerah naso-velo-orofaring. Terdapat empat derajat Friedman tongue position. Pemeriksaan ini dapat memprediksi ada tidaknya OSAS. Obstructive sleep apnea syndrome dapat dinilai menggunakan STOPBANG questionnaire, suatu instrumen yang dibuat untuk dapat secara cepat mendeteksi obstructive sleep apnea (OSA), dengan indikasi skor 5-8 risiko tinggi, 3-4 risiko sedang, dan $0-2$ risiko rendah. Metode penelitian ini adalah observasional dengan rancangan cross-sectional pada pasien strok iskemik fase akut berdasar atas hasil CT-scan kepala di RSAU dr. M. Salamun pada Agustus-Desember 2016. Analisis statistik menggunakan uji nonparametrik Kruskal-Wallis dan uji korelasi rank Spearman's. Total subjek penelitian 38 orang. Hasil penelitian menunjukkan bahwa terdapat hubungan bermakna antara derajat Friedman tongue position dan kejadian OSAS pada pasien strok di RSAU dr. M. Salamun dengan nilai $\mathrm{p}=0,007$. Simpulan, lidah merupakan struktur anatomi yang penting pada pasien OSA sehingga evaluasi posisi lidah penting untuk memprediksi tingkat keparahan OSA.
\end{abstract}

Kata kunci: Friedman tongue position, obstructive sleep apnea syndrome (OSAS), strok iskemik 


\section{Introduction}

The prevalence of stroke, in Indonesia, was 8.3 per 1,000 population, and the one diagnosed by health workers was 6 per 1,000 population. The data shows that around $72.3 \%$ of cases in the community diagnosed by health workers. There are 11 provinces in Indonesia, including West Java with the prevalence of stroke above national prevalence. ${ }^{1}$ Stroke classification based on anatomic pathology, and the cause consists of ischemic stroke and bleeding stroke. Research in hospitals of Denmark showed that the ischemic stroke rate was higher at $89.9 \%$ while bleeding stroke was 10.1\%. ${ }^{2}$ In China and Japan also showed ischemic stroke around $70-80 \%$ and bleeding stroke $20-30 \% .^{3}$ Stroke research by Misbach ${ }^{4}$ in Southeast Asia, ischemic stroke was $74 \%$ while bleeding stroke was around $26 \%$.

Stroke patients, especially ischemic stroke, can experience a variety of sleep disorders. Stroke is a disease that causes disability in the world's adult population in large numbers. Stroke patients often do not get adequate rehabilitation services so that when they return to work, they have limited function, weakness, sleep disturbances and psychological disorders. ${ }^{5}$

Types of sleep disorders in stroke patients depend on the neurological deficit they experience. Sleep disorder breathing (SDB), especially obstructive sleep apnea syndrome (OSAS) most commonly found in stroke patients (more than 50\%). SDB can be caused by stroke, mainly due to a disturbance in the respiratory center in brainstem or bulbar/pseudobulbar paralysis. ${ }^{6}$ Another sleep disorder that can occur in stroke patients is circadian rhythm disorder or sleep-wake disorder (SWD) which is about 20$40 \%$ of patients with stroke and insomnia. ${ }^{7}$

Sleep disorders in patients with ischemic stroke can occur because there is an obstruction in the upper airway. To facilitate the assessment of the upper airway, Friedman made a standard examination of the naso-velo-oropharynx region. There are four degrees of Friedman tongue position examination. First degree is patient able to open the mouth without removing the tongue; second degree, the entire uvula is visualized; third degree, the uvula is visualized, but the tonsils are not visible; and the fourth degree the mole palate is visualized, but the uvula is not visible; only the hard palate visualized. This examination can predict the presence or absence of OSAS.

We can assess OSAS using the STOP-BANG questionnaire. This instrument made to be able to quickly detect obstructive sleep apnea (OSA) sleep disorders, with an indication of a score of 5-8 for a high risk of OSA, 3-4 risks of OSA, and o-2 low risk of OSA. This paper will describe the relationship between the degree of Friedman tongue position and the incidence of obstructive sleep apnea syndrome in ischemic stroke sufferers.

\section{Methods}

The form of this study was observational with a cross-sectional study design, carried out in the Neurology Section of Air Force Hospital (Rumah Sakit TNI Angkatan Udara/RSAU) dr. M. Salamun Bandung from August to December 2016. The research subjects were all patients treated in the Neurology Section of RSAU dr. M. Salamun. The selection of research subjects based on arrival (consecutive admission sampling). Cases undergo a complete disease history, general physical examination, neurology examination, and neuroimaging head CT-scan. They then examined the degree of Friedman tongue position and filled STOP-BANG questionnaire.

This research approved by the Health Research Ethics Committee of Faculty of Medicine, Universitas Islam Bandung by ethics approval letter number: 386/Komite Etik.FK/IX/2016.

\section{Results}

Table 1 shows that the average age of ischemic stroke patients in RSAU dr. M. Salamun was 61.79 years old, standard deviation 9.39 years, median 62.00 years, with the youngest age was 42 years, and the oldest age was 83 years, most were in the 61-70 year age group.

The difference in BMI, the circumference of the neck and waistline between men and women in patients of ischemic stroke in RSAU dr. M. Salamun can be seen in Table 2. The results of the independent $t$ test on the degree of confidence $95 \%$ indicated that there was no statistically difference in BMI, between neck circumference, and the waistline between men and women in patients of ischemic stroke in RSAU dr. M. Salamun with value $\mathrm{p}=0.728, \mathrm{p}=0,105$ and $\mathrm{p}=0.943$ ( $\mathrm{p}$ value $>0.05$ ) respectivelly.

Relationship between the degree Friedman tongue position and obstructive sleep apnea is in Table 3. Table 3 shows that analysis of chi-square test on a 95\% degree of confidence showed there 
Table 1 Characteristics of Subjects based on Age and Sex

\begin{tabular}{lc}
\hline Age and Gender & $\mathbf{n = 3 8}$ \\
\hline Age (years) & \\
$41-50$ & 5 \\
$51-60$ & 12 \\
$61-70$ & 14 \\
$71-80$ & 6 \\
$81-90$ & 1 \\
Mean (SD): 61.79 (9.39) & Minimum: 42 \\
Median: 62.00 & Maximum: 83 \\
Gender & \\
Man & 15 \\
Woman & 23 \\
\hline
\end{tabular}

is a meaningful relationship between degrees of Friedman tongue position with OSAS ( $p$ value $=0.007, \mathrm{p} \leq 0.05$ ).

\section{Discussion}

Stroke is a disorder of brain functional focal and global acute, more than 24 hours, comes from blood flow disorder of the brain and is not caused by circulatory disorders of the brain at a glance, brain tumor, stroke or trauma due to a secondary infection. Ischemic or brain hemorrhage can cause a stroke with neurologic deficits that occur suddenly. Ischemic stroke caused by focal cerebral vascular occlusion, which causes a decline in the supply of oxygen and glucose to the brain undergoes occlusion. ${ }^{8}$

The risk of stroke was made up of their risk factors that cannot be changed such as age, gender, race, family history, history of transient ischemic attack (TIA), coronary heart disease, atrial fibrillation and heterozygous or homozygous for the homocystinuria, while the risk factors be changed i.e., hypertension, diabetes mellitus, smoking, alcohol and drug, hyperuricemia and other. ${ }^{9-11}$

The disease is the leading cause of death, and stroke disability chronicles the highest in the age groups above 45 years of age in Indonesia. ${ }^{9}$

Data from Table 1 showed the ischemic stroke mostly suffered by women and patients aged 6170 years-the results following the review of the literature and similar to several other studies.

The research in Solok Selatan General Regional Hospital showed many ischemic stroke sufferers were women $(32.29 \%)$ and may occur above 50 years old (45.83\%). ${ }^{10}$ A study conducted in Prof. Dr. R. D. Kandou General Hospital Manado July 2012-June 2013 period also showed many ischemic stroke sufferers were at the age range 51-65 years. ${ }^{11}$

Research in Dr. Saiful Anwar Regional General Hospital during 1 July-31 December 2012 showed similar data that many ischemic strokes occur in women (58\%) and patients aged $65-74$ years $(31.6 \%){ }^{12}$

The ischemic stroke can occur regardless of the age, but the pattern of ischemic stroke disease tends to occur in older age groups due to impaired blood flow which is very dependent on the condition of the blood vessels. Blood vessels in older people likely to experience changes in a degenerative way, and as the result of the process of atherosclerosis. The speed of the process of the blood vessel impairment to stroke depends on the lifestyle, eating patterns, and behavior of a person. ${ }^{11}$

Gender becomes a risk factor for the occurrence of stroke, especially in women because women have the hormone estrogen that helps HDL LDL catabolism and hepatic. Decrease LDL catabolism due to the decrease in estrogen levels that it can increase the risk of the occurrence of

Table 2 The Difference in BMI, the Circumference of the Neck and Waistline between Men and Women in Patients of Ischemic Stroke in RSAU dr. M. Salamun

\begin{tabular}{lccccc}
\hline \multirow{2}{*}{ Variables } & \multicolumn{2}{c}{ Man } & \multicolumn{2}{c}{ Woman } & \\
\cline { 2 - 5 } & $\begin{array}{c}\text { Mean } \\
\text { (SD) }\end{array}$ & $\begin{array}{c}\text { Median } \\
\text { (Min-Max) }\end{array}$ & $\begin{array}{c}\text { Mean } \\
\text { (SD) }\end{array}$ & $\begin{array}{c}\text { Median } \\
\text { (Min-Max) }\end{array}$ & p Value \\
\hline BMI & $23.26(2.94)$ & $22.66(19.20-27.68)$ & $23.65(3.61)$ & $23.40(17.70-33.20)$ & 0.728 \\
$\begin{array}{l}\text { Neck } \\
\text { circumference }\end{array}$ & $36.93(3.15)$ & $38.00(31-43)$ & $34.70(4.53)$ & $35(27-44)$ & 0.105 \\
$\begin{array}{l}\text { Abdominal } \\
\text { circumference }\end{array}$ & $88.07(13.15)$ & $90.00(62-108)$ & $87.78(11.02)$ & $86(71-111)$ & 0.943 \\
\hline
\end{tabular}


Table 3 Relationship on the Friedman Tongue Position Degree and Obstructive Sleep Apnea Syndrome

\begin{tabular}{|c|c|c|c|c|c|}
\hline \multirow{2}{*}{$\begin{array}{l}\text { Obstructive Sleep } \\
\text { Apnea Syndrome }\end{array}$} & \multicolumn{4}{|c|}{ Degrees Friedman Tounge Position } & \multirow[b]{2}{*}{ p Value } \\
\hline & $\begin{array}{l}\text { Degree I } \\
\text { (n) }\end{array}$ & $\begin{array}{c}\text { Degree II } \\
\text { (n) }\end{array}$ & $\begin{array}{c}\text { Degree III } \\
\text { (n) }\end{array}$ & $\begin{array}{c}\text { Total } \\
\text { (n) }\end{array}$ & \\
\hline Low risk & 3 & 7 & $\mathrm{o}$ & 10 & \\
\hline Medium risk & 3 & 12 & o & 15 & 0.07 \\
\hline High risk & o & 9 & 4 & 13 & \\
\hline
\end{tabular}

*Chi-square test

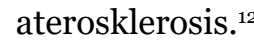

Obstructive sleep apnea is a disorder that is part of the sleep-disorder breathing syndrome complex. OSA is the state of occurrence of upper airway obstruction periodically during sleep that causes intermittent breath stop, either complete (apnea) or partial (hypopnea). ${ }^{13}$

Obesity is a risk factor for going to his various diseases in developing countries and the developing countries, for example, the disease due to obesity, such as type II DM, hypertension, cardiovascular disease, obstruction sleep apnea/ hypopnea syndrome (OSAHS). ${ }^{14}$

A variety of methods can be used to find out the Anthropometry happened his obesity; these methods include measurement of BMI, waist circumference, hip circumference, arm circumference, and circumference of the neck. ${ }^{14}$

Table 2 shows the value of BMI, the circumference of the neck, and the waist circumference increased in ischemic stroke patients who have OSA..$^{15-17}$

Obesity can alter the volume and shape of the anatomy of the tongue so that the tongue raises that will ultimately reduce the volume of the upper respiratory tract. ${ }^{13}$

Based on the results of the study revealed that the likelihood of obesity could worsen OSA because of fat deposits on the specific location. The buildup of fat in the tissue around the airway the top producing lumen airway smaller and improvement of collapsibility of the upper respiratory tract, so that contribute to the onset of apnea. ${ }^{18}$

The form of the oropharynx and hypopharynx changed significantly to the increase of the BMI. The higher the BMI, the transverse diameter of the oropharynx and hypopharynx lumen will decrease and subsequently related to obstructive sleep apnea. ${ }^{19}$
Neck circumference reflects regional obesity around the pharynx as the upper respiratory tract and has a stronger correlation value against the risk of OSA compared with BMI. The amount of adipose tissue deposits below the pharynx has a relationship with the OSA risk and the degree of severity, proven by studies on obese individuals. Obese individuals have a more visceral adipose tissue compared to non-OSA individual..$^{20}$

The result from this research was similar to the Schafer. Its report that the risk of OSA has a stronger correlation with the accumulation of adipose tissue in the intra-abdomen regio than neck regio or BMI. It is proof that waist circumference is a good predictor of OSA than the neck circumference or BMI. So it can be inferred, the accumulation of adipose tissue in the pharynx or neck and intra-abdominal regio, may very well be a strong predictor and contribute to the pathogenesis of the occurrence of OSA. It may become a possible influence on the pathogenesis of OSA via different mechanisms. ${ }^{20}$

Evaluation of anatomy of the upper respiratory path is part of the physical examination in people with obstructive sleep apnea. Inspection there is an abnormality of structure or the narrowness of the channel the breath over often found in obstructive sleep apnea patients. Friedman tongue position is one way the physical examination are quick to predict the existence and severity of obstructive sleep apnea..$^{21}$

From Table 3 obtained, the results are there is a relationship between degrees of Friedman's tongue position and obstructive sleep apnea in patients of ischemic stroke in RSAU dr. M. Salamun. The result is following the various reviews of the literature and previous researches. ${ }^{21-23}$

Three factors play a role in the pathogenesis of obstructive sleep apnea, i.e., the pharyngeal 
area for breath channel obstruction. The enlargement of the tongue can cause occlusion of the nasopharynx and oropharynx, causing airflow cessation although respiratory process continue while sleeping. ${ }^{24}$

The tongue is an essential anatomical structure in obstructive sleep apnea patients so that evaluation of the tongue is vital for predicting the severity of obstructive sleep apnea. ${ }^{25}$

Soft palate, tonsil, and base of the tongue is the main component in the oropharynx and hypopharynx. The size and shape of these three structures can affect the size of the oropharynx and subsequent events related to obstructive sleep apnea. ${ }^{26}$

To evaluate the closure of channels breath, it is essential to know is the size of the pharynx, especially the oropharynx. The oropharynx channel size is determined by the walls which form the channel, i.e., anterior, posterior, and lateral wall. The palate mole and tongue form the anterior wall of the oropharynx. The posterior wall of the oropharynx is formed by superior constrictor muscles, medially, and inferiorly. The lateral wall of the oropharynx formed by the muscles of the oropharynx, namely styloglossus, palatopharyngeus, palatoglossus, stylopharyngeus, hyoglossus, stylohyoid, and superior pharyngeal constrictor, medial and inferior. ${ }^{27}$

\section{Conclusion}

There is a relationship between the degree of Friedman tongue position and obstructive sleep apnea syndrome in patients of ischemic stroke in RSAU dr. M. Salamun Bandung.

\section{Conflict of Interest}

All authors declare that there was no conflict of interest in this article.

\section{Acknowledgements}

The Director and Neurology staff of RSAU dr. M. Salamun Bandung for the assistance.

\section{References}

1. Lloyd-Jones D, Adams RJ, Brown TM, Carnethon M, Dai S, De Simone G, et al. Heart disease and stroke statistics 2010 update: a report from the American Heart Association. Circulation. 2010;121(7):948-54.

2. Kusuma Y, Venketasubramanian N, Kiemas LS, Misbach J. Burden of stroke in Indonesia. Int J Stroke. 2009;4(5):379-80.

3. Misbach J, Ali W. Stroke in Indonesia: a first large prospective hospital based study of acute stroke in 28 hospitals in Indonesia. $\mathbf{J}$ Clin Neurosci. 2001;8(3):245-9.

4. Misbach J. Pattern of hospitalized-stroke patients in ASEAN countries an ASNA stroke epidemiology study. Med J Indones. 2001;10:48-56.

5. Kim J, Kim Y, Yang KI, Kim DE, Kim SA. The relationship between sleep disturbance and functional status in mild stroke patients. Ann Rehabil Med. 2015;39(4):545-52.

6. Jennum P, Santamaria Cano J, Bassetti C, Clarenbach P, Hölg B, Mathis J, et al. Sleep disorders in neurodegenerative disorder and stroke. In: Gilhus NE, Barnes Michael R, Brainin M, editors. European handbook of neurological management. $2^{\text {nd }}$ Edition. Volume 1. Chichester, England: WileyBlackwell; 2011. p. 529-43.

7. National Stroke Association. Recovery after stroke: sleep disorders [Internet]. 2006 [cited 2017 January 30]. Available from: https://tbigroup.weebly.com/ uploads/4/7/2/1/4721501/sleep_disorders. pdf.

8. Setyopranoto I. Stroke: gejala dan penatalaksanaan. CDK. 2011;38(4):247-50.

9. Riyadina W, Rahajeng E. Determinan penyakit stroke. Kesmas. 2013;7(7):324-30.

10. Dinata CA, Safrita Y, Sastri S. Gambaran faktor risiko dan tipe stroke pada pasien rawat inap di Bagian Penyakit Dalam RSUD Kabupaten Solok Selatan periode 1 Januari 2010-31 Juni 2012. JKA. 2013;2(2):57-61.

11. Kabi GYCR, Tumewah R, Kembuan MAHN. Gambaran faktor risiko pada penderita stroke iskemik yang dirawat inap neurologi RSUP Prof. Dr. R.D. Kandau Manado periode Juli 2012-Juni 2013. J e-CliniC (eCl). 2015;3(1):457-62.

12. Astutik W, Hasmono D, Syifa N. Penggunaan obat golongan diuretik pada pasien stroke iskemik di Instalasi Rawat Inap RSU Dr. Saiful Anwar Malang. Media Farmasi. 2013;10(2):84-93.

13. Cahyono A, Hermani B, Mangunkusumo E, Perdana RS. Hubungan obstructive 
sleep apnea dengan penyakit sistem kardiovaskuler. ORLI. 2011;41(1):37-45.

14. Laoh VCE, Tanudjaja GN, Ticoalu SHR. Hubungan lingkar leher dengan obesitas pada mahasiswa Fakultas Kedokteran Sam Ratulangi. J e-Biomedik (eBM). 2013;1(2):901-6.

15. Hingorjo MR, Qureshi MA, Mehdi A. Neck circumference as a useful marker of obesity: a comparison with body mass index and waist circumference. J Pak Med Assoc. 2012;62(1):36-40.

16. World Health Organization (WHO). Waist circumference and waist-hip ratio: report of a WHO Expert Consultation. Geneva, Switzerland: WHO Press; 2008.

17. WHO Expert Consultation. Appropriate body-mass index for Asian populations and its implications for policy and intervention strategies. Lancet. 2004;363(9403):157-63.

18. Romero-Corral A, Caples SM, Lopez-Jimenez F, Somers VK. Interactions between obesity and obstructive sleep apnea: implication for treatment. Chest. 2010;137(3):711-9.

19. Mayer P, Pépin JL, Bettega G, Veale D, Ferreti G, Deschaux C, et al. Relationship between body mass index, age and upper airway measurements in snorers and sleep apnea patients. Eur Respir J. 1996;9(9):1801-9.

20. Isono S. Obstructive sleep apnea of obese adults: pathophysiology and perioperative airway management. Anesthesiology. 2009;110(4):908-21.

21. Friedman M, Hamilton C, Samuelson CG, Lundgreen ME, Pott T. Diagnostic value of the
Friedman tongue position and Mallampati classification for obstructive sleep apnea: a meta-analysis. Otolaryngol Head Neck Surg. 2013;148(4);540-7.

22. Rodrigues MM, Dibbern RS, Goulart CWK, Palma RA. Correlation between the Friedman classification and the Apnea-Hypopnea Index in a population with OSAHS. Braz $\mathrm{J}$ Otorhinolaryngol. 2010;76(5):557-60.

23. Friedman M, Soans R, Gurpinar B, Lin HC, Joseph NJ. Interexaminer agreement of Friedman tongue positions for staging of obstructive sleep apnea/hypopnea syndrome. Otolaryngol Head and Neck Surg. 2008;139(3):372-7.

24. Cahyono A, Hermani B, Mangunkusumo E, Perdana RS. Hubungan obstructive sleep apnea dengan penyakit sistem kardiovaskuler. ORLI. 2011;41(1):37-45.

25. Ahn SH, Kim J, Min HJ, Chung HJ, Hong $\mathrm{JM}$, Lee JG, et al. Tongue volume influences lowest oxygen saturation but not ApneaHypopnea Index in obstructive sleep apnea. PLoS One. 2015;10(8):e0135796.

26. Rabadi D, Baker AA, Al-Qudah M. Correlation between oro and hypopharynx shape and position with endotracheal intubation difficulty. Rev Bras Anetesiol. 2014;64(6):433-7.

27. Schwab RJ, Remmers JE, Kuna ST. Anatomy and physiology of upper airways obstruction. In: Kryger MH, Roth T, Dement WC, editors. Principles and practice of sleep medicine. $5^{\text {th }}$ Edition. St. Louis, USA: Saunders; 2011. p. 1153-71. 